\title{
A tüdőartériák intimájából kiinduló sarcoma
}

\author{
Sejben Anita dr. ${ }^{1}$. Tiszlavicz László dr. ${ }^{1}$ - Furák József dr. ${ }^{2}$ \\ Boros Krisztina dr. ${ }^{3}$ - Sápi Zoltán dr. ${ }^{4}$ - Zombori Tamás dr. ${ }^{1}$ \\ 'Szegedi Tudományegyetem, Általános Orvostudományi Kar, Pathologiai Intézet, Szeged \\ ${ }^{2}$ Szegedi Tudományegyetem, Általános Orvostudományi Kar, Sebészeti Klinika, Szeged \\ ${ }^{3}$ Csongrád Megyei Mellkasi Betegségek Szakkórháza, Szeged \\ ${ }^{4}$ Semmelweis Egyetem, Általános Orvostudományi Kar, I. Patológiai és Kísérleti Rákkutató Intézet, Budapest
}

\begin{abstract}
A pulmonalis arterialis intimalis sarcoma ritka, magas mortalitású daganat, mely lokalizációja miatt a pulmonalis embolia, valamint a tüdőgyulladás tünettanát utánozhatja. A diagnózis felállítása és a megfelelő kezelés kiválasztása körül számos kérdés merülhet fel. Egy 46 éves, korábban hereseminoma, pulmonalis embolia, asztma, valamint pollenallergia miatt kezelés alatt álló férfi kontroll mellkasi CT-felvételén bal oldalon a mediastinalis pleurát infiltráló, az arteria pulmonalist teljesen elzáró, összességében 7-8 cm-es térfoglaló folyamatot írtak le. A hörgőbiopsziás mintából orsósejtes tumor diagnózisa született, illetve leiomyoma, leiomyomatosus hyperplasia, illetve leiomyosarcoma lehetőségét vetették fel. A fennálló obstrukció miatt a beteg bal oldali tüdőeltávolításon esett át. A szövettani vizsgálat a pulmonalis artériákban terjedő, orsósejtes daganatot kórismézett, immunhisztokémiailag diffúz SMA- és fokális MDM2pozitivitással, valamint magas proliferációs aktivitással. A h-caldesmon, az S100 protein, az ERG, valamint a pancitokeratin-immunfestések negatívnak bizonyultak. Fluoreszcens in situ hibridizációval a tumorsejtek mintegy $10 \%$-ában polysomiát, illetve MDM2-amplifikációt lehetett igazolni, aminek alapján a „high-grade” pulmonalis arterialis intimalis sarcoma diagnózisa megerősítésre került. Féléves követés alatt a betegség nem újult ki. A pulmonalis arterialis intimalis sarcoma pontos incidenciája nem ismert. Egyes források szerint a krónikus pulmonalis hypertoniás betegek 1-4\%-ánál fordul elő. A tünetek közül a fogyás kelti fel a leginkább a daganatos betegség gyanúját. A képalkotó és a kórszövettani vizsgálatoknak kulcsszerepük van a diagnózis felállításában. A daganat rossz kórjóslata miatt a minél korábbi felismerés és a kemoterápiával kombinált sebészi kezelés javíthatja a túlélési lehetőségeket.
\end{abstract}

Orv Hetil. 2020; 161(6): 232-236.

Kulcsszavak: pulmonalis arterialis intimalis sarcoma, fluoreszcens in situ hibridizáció, immunhisztokémia, pulmonectomia

\section{Intimal sarcoma of pulmonary arteries}

Pulmonary arterial intimal sarcoma is a rare tumour with high mortality. Due to its localisation, the symptoms can mimic pulmonary thromboembolism and pneumonia, therefore assessing the diagnosis and choosing the adequate therapy is never easy. Its therapy mainly consists of surgery combined with radiochemotherapy. A 46-year-old male patient with testicular seminoma, pulmonary embolism, bronchial asthma and pollen allergy in his history had a follow-up thoracic CT. On the left side of the lung, a pleura-infiltrating 7-8 cm lesion, which occluded the pulmonary artery, was described. The first biopsy specimen showed fragments of spindle cell tumour. The primary diagnosis was leiomyoma, leiomyomatous hyperplasia, yet the presence of leiomyosarcoma could not have been ruled out. Due to the arterial obstruction, the patient underwent left sided pulmonectomy. Histological examination showed a tumour mostly composed of spindle cells that were diffusely positive with SMA, focally diffuse with MDM2 immunohistochemistry together with high proliferation activity. h-Caldesmon, S-100, ERG and pancytokeratin expressions were not detected. With fluorescent in situ hybridization $10 \%$ of tumour cells showed polysomy and MDM2 amplification. According to the results, high-grade pulmonary arterial intimal sarcoma diagnosis has been made. The precise incidence of pulmonary arterial intimal sarcoma is unknown. Some literature data suggest it can be the cause of chronic pulmonary hypertension in $1-4 \%$ of the cases. Weight loss can draw attention to the malignant nature of the disease. Imaging techniques and histology are the gold standard in setting the diagnosis. The prognosis is poor. Early recognition and surgery combined with chemotherapy can prolong survival. 
Keywords: pulmonary arterial intimal sarcoma, fluorescent in situ hybridization, immunohistochemistry, pulmonectomy

Sejben A, Tiszlavicz L, Furák J, Boros K, Sápi Z, Zombori T. [Intimal sarcoma of pulmonary arteries]. Orv Hetil. 2020; 161(6): 232-236.

(Beérkezett: 2019. szeptember 22.; elfogadva: 2019. október 13.)

\section{Rövidítések}

ALKI = (anaplastic lymphoma kinase 1$)$ anaplasticus lymphoma kináz- $1 ; \mathrm{CD}=$ (cluster of differentiation) differenciációs klaszter; $\mathrm{CT}=$ (computed tomography) számítógépes tomográfia; $\mathrm{ERG}=$ (erythroblast transformation-specific [ETS]-related gene) erythroblasttranszformáció-specifikus doménhez (ETS) kapcsolt gén; FISH = fluoreszcens in situ hibridizáció; Ki67 = Ki67 proliferációs marker; MDM2 = mouse double minute 2 homolog; PAIS = pulmonalis arterialis intimalis sarcoma; PDGF = (platelet-derived growth factor $)$ vérlemezkéből származó növekedési faktor; PDGFRA = (platelet-derived growth factor receptor A) vérlemezkéből származó növekedési faktor receptor $\mathrm{A}$; PET = (positron-emission tomography) pozitronemissziós tomográfia; SMA $=$ (smooth muscle actin $)$ simaizomaktin; STAT6 $=($ signal transducers and activators of transcription 6) jelátviteli és transzkripciós aktivátorok-6

A pulmonalis arterialis intimalis sarcoma (PAIS) ritka, magas mortalitású, agresszív daganat [1]. Lokalizációja miatt a pulmonalis thromboembolia, valamint a tüdőgyulladás tünettanát utánozhatja, így a diagnózis felállítása és a megfelelő kezelés kiválasztása nemritkán kihívásokat jelent [2-4]. Szövettani megjelenése változatos, osteosarcoma és chondrosarcoma komponenst tartalmazhat, azonban teljes mértékben dedifferenciált megjelenésü is lehet [3]. Kezelése elsősorban sebészi (pulmonectomia vagy pulmonalis endarterectomia), melyet a legtöbb esetben kemoterápiával egészítenek ki [5-8]. Az átlagos túlélési idő terápia nélkül másfél hónap, míg a kezelt esetekben átlagosan egy év [7,9].

\section{Esetbemutatás}

A 46 éves férfi beteg kórelőzményéből kiemeljük, hogy 2000-ben hereseminomával észlelték, továbbá 2017-ben bal oldali segmentalis pulmonalis embolia miatt kezelték, valamint gyermekkora óta pollenallergiában és asztmában szenvedett. Családjában előfordult asztmás, illetve daganatos megbetegedés egyaránt. Kontroll mellkasi CT-felvételén 2019 februárjában bal oldalon a paramediastinalis mellhártyát infiltráló, az arteria pulmonalist teljesen elzáró, összességében $70-80 \mathrm{~mm}$-es térfoglaló folyamatot igazoltak. Az elváltozásból a Csongrád Megyei Mellkasi Betegségek Szakkórházában bronchoszkópos mintavétel történt, amelynek során $\mathrm{l} \times \mathrm{l} \times 0,5 \mathrm{~mm}$ es szövetmintát nyertek. A kórszövettani vizsgálat során a biopsziás mintában a hörgőnyálkahártya alatt dagana- tos orsósejtek proliferációját figyelték meg. A daganatsejtek a mérsékelt citológiai atípia jeleit mutatták. Kifejezetten emelkedett mitotikus aktivitás nem volt. Immunhisztokémiai vizsgálattal a daganat vimentin- és SMApozitívnak, CD34- és STAT6-negatívnak bizonyult. A Ki67 markerrel mintegy 3\%-os proliferációs aktivitás mutatkozott. A kicsiny minta alapján határozott vélemény nem született. Differenciáldiagnosztikailag a leiomyomatosus hyperplasia, a leiomyoma, valamint az alacsony malignitású leiomyosarcoma lehetősége merült fel. Az onkoteam a szövettani lelet birtokában a fennálló artériás obstrukció miatt a resectio mellett foglalt állást. A betegnél totális bal oldali pulmonectomiát hajtottak végre a Szegedi Tudományegyetem Sebészeti Klinikáján. A mútét során döntően a bal felső lebenyt és kis mértékben az alsó lebenyt érintő daganatot észleltek, mely az arteria pulmonalis lumenében is tapintható volt. A preparátum makroszkópos vizsgálata során az erek lumenébe boltosuló, a lument öntvényszerúen kitöltő, tömött, szürkésfehér idegen szövet tûnt szembe, amely mindkét tüdőlebenyt érintette ( $1 / A$ ábra). A metszéslapon fényes, porc- vagy csontszerú állomány nem mutatkozott. Az elváltozás gócosan az erek melletti tüdőállományba terjedt.

A reszekátum kimetszéseiben az intravascularis daganatot $(1 / B$ ábra) orsósejtek alkották, melyek kötegekbe, helyenként örvényekbe rendeződtek. Kifejezett volt a sejtmagok alaki és méretbeli különbsége, többmagvú daganatos óriássejtek ( $1 / C$ ábra), valamint necrosis is megfigyelhető volt. A proliferációs aktivitást jellemző Ki67expresszió a sejtek $60 \%$-át jelölte. Immunhisztokémiai vizsgálattal a daganatsejtekben diffúz simaizomaktin $(1 / D)$ - és fokális MDM2-expresszió mutatkozott ( $1 / E$ ábra). A h-caldesmon-, az S100-, az ERG-, valamint a pancitokeratin (AEl/AE3)-reakciók negatívnak bizonyultak. A proliferációs aktivitást jellemző Ki67-expreszszió a sejtek $60 \%$-át jelölte $(1 / C$ és $D$ ábra). Figyelembe véve a szöveti megjelenést, az immunhisztokémiai vizsgálatok eredményét és az intraarterialis növekedést, a PAIS volt az előzetes kórisménk, és differenciáldiagnosztikai lehetőségként a leiomyosarcoma lehetőségét vetettük fel. A daganat kizárólag a tüdőre lokalizálódott, aminek alapján a tumort a pTl-es kategóriába soroltuk. A tumor a zsigeri mellhártya elasztikus rostjait áttörte, azonban a mellhártya felszínére nem terjedt ki. A reszekciós hörgőcsonktól és a peribronchialis reszekciós felszíntől távol helyezkedett el. A vérérterjedés jelei mutat- 


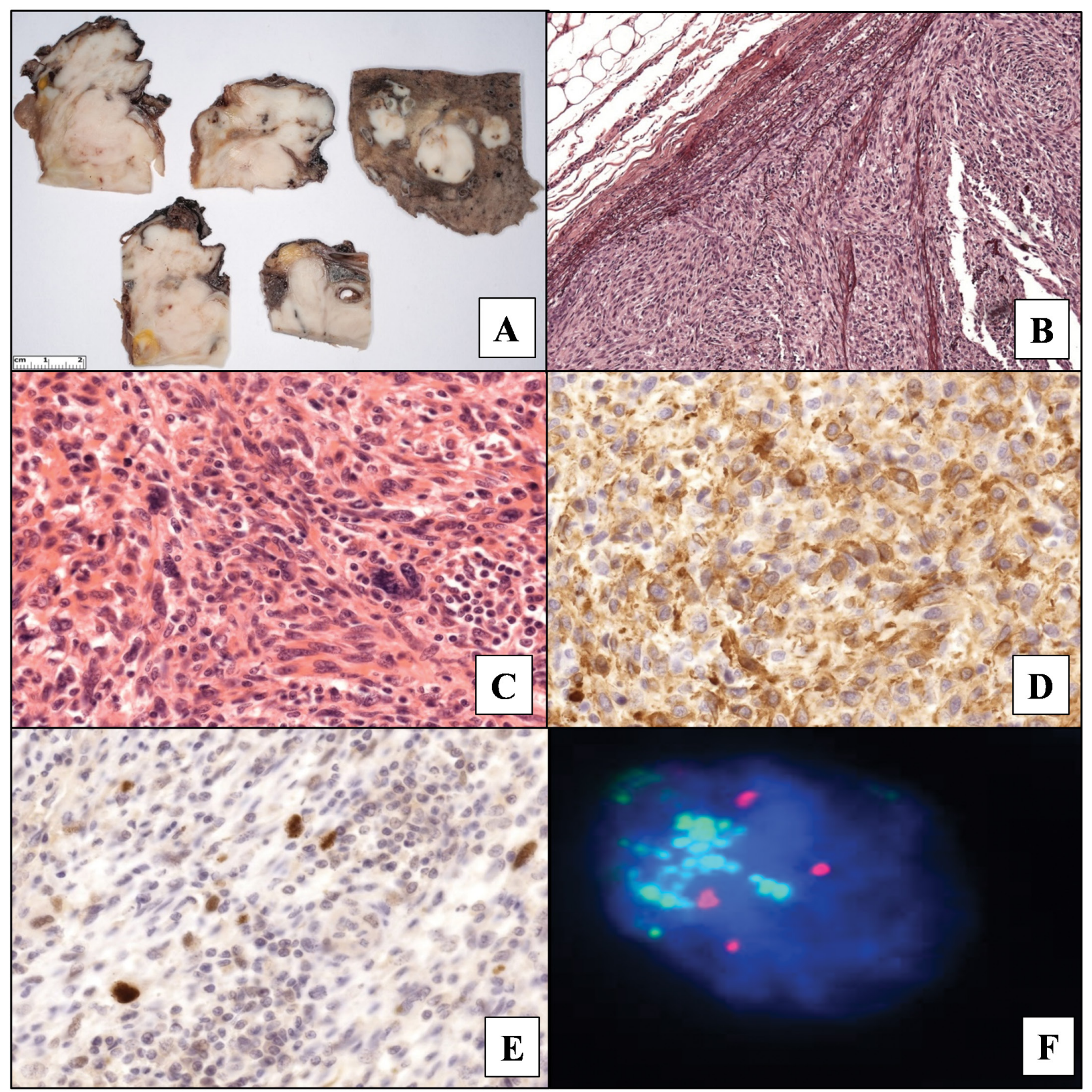

1. ábra A: A tüdő centrális részén az erek lumenébe boltosuló, tömött, szürkésfehér idegen szövet látszódik
B: Orceinfestéssel a daganatnak az arteria pulmonalis lumenébe való terjedése figyelhetó meg. A daganat az érfal elasztikus rostjait megkíméli
(orcein, $10 \times$ )
C: Nagyobb nagyításon a kötegekbe rendeződő orsósejtek kifejezett atípiát mutatnak, nemritkán daganatos óriássejtet képezve (HE, 40x)
D: SMA immunhisztokémiai reakcióval a daganatsejtekben diffúz $3+$ citoplazmatikus pozitivitás mutatkozik (SMA-IHC, 40×)
E: MDM2 immunhisztokémiai reakcióval fokális nukleáris pozitivitás észlelhető (MDM2-IHC, $40 \times$ )
F: Az MDM2 FISH-vizsgálata során a zöld szignálok az MDM2-polysomiát és -amplifikációt, a piros szignálok a 12-es kromoszóma centromerikus
régióját jelölték
FISH = fluoreszcens in situ hibridizáció; HE = hematoxilin-eozin; IHC = immunhisztokémia; MDM-2 = mouse double minute 2; SMA = simaizom-
aktin

koztak. Egyértelmü nyirokér-, perineuralis és légúti propagáció a mintában nem volt jelen.

Az eset második véleményezésre az I. Patológiai és Kísérleti Rákkutató Intézetbe került. További immunhisztokémiai vizsgálatok készültek: a daganat ALKI-, CD23-, CD21-reakciókkal negatívnak bizonyult. FISH-vizsgálat elvégzését követően MDM2-amplifikáció tekintetében a tumorsejtek mintegy 10\%-ában polysomiát, illetve MDM2-amplifikációt lehetett igazolni ( $1 / F$ ábra). Mindezek alapján a „high-grade” PAIS diagnózisa megerősítésre került. A posztoperatív időszak eseménytelenül zajlott. A féléves követési időszakban a rendszeres kontrollvizsgálatokon recidíva, valamint áttét nem igazolódott. 


\section{Megbeszélés}

A PAIS pontos incidenciája ismeretlen, és előfordulását valószínúleg alulbecsülik [10]. Anderson és mtsa, valamint Bernard és mtsa kimutatták, hogy a krónikus pulmonalis hypertoniás betegek thromboendarterectomiás mintáinak 1-4\%-ában észlelhető PAIS [11, 12]. Mussot és $m$ tsai eredményei szerint a daganat elsősorban közép- és időskorú betegek körében fordul elő (átlagéletkor: 56 év, 26-78) [10]. A betegség vezető klinikai tünete a nehézlégzés, amelyet mellkasi vagy hátfájdalom, köhögés, vérköpés, testsúlycsökkenés, láz, ájulásszerü rosszullét kísérhet. A tünetek a leginkább az akut vagy krónikus tüdőembolia és a pulmonalis hypertonia sajátságait utánozzák [13]. A daganatos betegség gyanúját a testsúlycsökkenés, az anaemia, a láz és az étvágytalanság keltheti fel [14]. További klinikai manifesztáció lehet az idült jobbszívfél-elégtelenség és a pulmonalis arteria aneurysma $[15,16]$. A fizikális vizsgálatok során a jugularis vena distensio, a cianózis, a perifériás vizenyő, a szisztolés ejekciós zörej, a hepatosplenomegalia és a dobverőujjak emelendők ki. A képalkotó vizsgálatok közül a CT, a CT-angiográfia és a PET-CT az elsődleges választás. A CT- és CT-angiográfiás vizsgálatok során a daganat általában a centrális tüdőartériákban telődési hiányokat okozó, lobulált növedékként jelentkezik. A PET-CT segítségével az intenzív fluor-dezoxi-glükóz felvétele segít a pulmonalis thromboemboliától való elkülönítésében [17].

A daganat a pulmonalis billentyütől a lebenyi ágakig bárhol kialakulhat. Általában egyoldali folyamat, de nem ritka a kétoldalúság sem. Tekintettel arra, hogy a pulmonalis embolia a legtöbbször kétoldali, egyoldali intraarterialis térfoglaló folyamat esetén a PAIS gyanúja felvethető [18].

A kórisme felállításának alapvető módszere a kórszövettani vizsgálat. A szövetmintanyerés történhet transbronchialis biopszia segítségével vagy sebészi úton (embolectomia vagy - mint esetünkben - pulmonectomia során). A daganat szöveti képe igen változatos megjelenésű lehet. A két leggyakoribb mintázat a differenciálatlan pleiomorph sarcoma és a „low-grade” orsósejtes sarcoma myxoid háttérrel. Hatból egy esetben heterológ differenciáció jeleként chondrosarcoma, illetve osteosarcoma komponens is jelen lehet. További heterológ komponens lehet a rhabdomyosarcoma, a leiomyosarcoma, az epitheloid sejtes vagy kerek sejtes differenciálatlan sarcoma, a synovialis sarcoma, az epitheloid haemangioendothelioma, az angiosarcoma vagy a „low-grade” gyulladásos myofibroblastos sarcoma $[19,20]$. A sajátos elhelyezkedés és a szöveti kép mellett speciális vizsgálatok is szükségesek a diagnózis felállításához. Az immunhisztokémiai vizsgálatok során a differenciálatlan területeken a daganatsejtek általában vimentin- és aktin pozitívak, míg a speciális differenciációjú területek az azoknak megfelelő immunfenotípust mutatnak. A tumorra jellemző genetikai eltérések közül a legtöbb daganat esetében
MDM2-amplifikációt lehet észlelni [21]. A 12-es kromoszómán elhelyezkedő MDM2-es onkogén által kódolt MDM2-es onkoprotein egészséges sejtekben a p53-as tumorszuppresszor fehérje ubikvitinálásáért felelős, így a lebontásában múködik közre. Az MDM2 amplifikációja, illetve overexpressziója szerepet játszik bizonyos daganatok (például liposarcoma) patogenezisében. Mint esetünkben bemutattuk, az onkoprotein kimutatására immunhisztokémiai, az onkogén amplifikációjának igazolására fluoreszcens in situ hibridizációs technikát alkalmaztunk. További gyakori genetikai eltérés a PAIS esetében a PDGFRA-amplifikáció [22]. Az ezen a sejtmembránon elhelyezkedő receptor a PDGF-t és izoformáit érzékeli, valamint olyan jelutakat aktivál, amelyek celluláris növekedéshez és differenciációhoz vezetnek. A PDGFRA-gén bizonyítottan szerepet játszik több myeloid és lymphoid daganat kialakulásában [23].

A betegség prognózisát illetően igen kevés adat áll rendelkezésre. Keel és mtsai vizsgálatában a betegek teljes túlélése a sebészi kezelést követő harmadik évben mintegy $70 \%$ volt [24]. Bacha és mtsai, valamint Blackmon és mtsai eredményei alapján azon betegek medián túlélése volt 3 év, akik kuratív sebészeti beavatkozáson estek át. Azon betegeknél, akiknél a reszekció inkomplett volt, a medián túlélés egy évnél kevesebbnek bizonyult $[25,26]$.

$\mathrm{Az}$ alacsony grádusú daganatok (például leiomyosarcoma, low-grade inflammatoricus myofibroblastos tumor) esetében jobb a prognózis [27]. Habár a sebészi kezelés és az azt követő kemoterápia a kezelés legelfogadottabb módja [28-30], a kemoterápia és/vagy a radioterápia hatékonyságát illetően megoszlanak a vélemények [10, 31]. Kriz és mtsai esetismertetésükben a dakarbazin- és a doxorubicinkezelés hatékonyságára hívták fel a figyelmet [2]. Célzott kezelés lehetőségeként az angiogenezis-gátlókkal történtek ígéretes kísérletek [32].

\section{Következtetés}

Esetbemutatásunkkal szeretnénk felhívni figyelmet egy ritka, pulmonalis emboliát utánzó betegségre. A tumor igen kedvezőtlen kórjóslata miatt a diagnózis mihamarabbi felállítására kell törekedni, hogy a beteg sebészi reszekcióban és kemoterápiában részesülhessen. A CT, a PET-CT és a bronchoszkópos mintavétel biztosíthatja a szövetmintát, amelyen immunhisztokémiai reakciók és FISH segítségével a betegség kórismézhető.

Anyagi támogatás: A kutatás és a kézirat megírása anyagi támogatásban nem részesült.

Szerzői munkamegosztás: S. A.: A kézirat megszövegezése. T. L., F. J.: Szakmai véleményezés. B. K.: Adatgyüjtés, szakmai véleményezés. S. Z.: A FISH-vizsgálat elvégzése, szakmai véleményezés. Z. T.: Adatgyưjtés, 
szakmai véleményezés, a kézirat megírásának koordinálása. A cikk végleges változatát valamennyi szerző elolvasta és jóváhagyta.

Érdekeltségek: A szerzőknek nincsenek érdekeltségeik.

\section{Köszönetnyilvánítás}

Köszönetünket fejezzük ki Dezső Mihálynak a szövettani képek biztosításáért.

\section{Irodalom}

[1] Ozbek C, Emrecan B, Calli AO, et al. Intimal sarcoma of the pulmonary artery with retrograde extension into the pulmonic valve and right ventricle. Tex Heart Inst J. 2007; 34: 119-121.

[2] Kriz JP, Munfakh NA, King GS, et al. Pulmonary artery intimal sarcoma: a case report. Case Rep Oncol. 2016; 9: 267-272.

[3] Kim C, Kim MY, Kang JW, et al. Pulmonary artery intimal sarcoma versus pulmonary artery thromboembolism: CT and clinical findings. Korean J Radiol. 2018; 19: 792-802.

[4] Yano C, Tominaga M, Miwa K, et al. A case of primary pulmonary artery intimal sarcoma. Int J Respir Pulm Med. 2018; 5: 083. doi: $10.23937 / 2378-3516 / 1410083$.

[5] Noguchi T, Gomi D, Fukushima T, et al. A case of unresectable pulmonary artery intimal sarcoma with prolonged survival by chemotherapy. Case Rep Oncol. 2019; 12: 192-198.

[6] Cantaloube M, Moureau-Zabotto L, Mescam L, et al. Metastatic intimal sarcoma of the pulmonary artery sensitive to carboplatin-vinorelbine chemotherapy: case report and literature review. Case Rep Oncol. 2018; 11: 21-28.

[7] Secondino S, Grazioli V, Valentino F, et al. Multimodal approach of pulmonary artery intimal sarcoma: a single-institution experience. Sarcoma 2017; 2017: 7941432.

[8] Aso T, Terao M, Endo H, et al. A case of pulmonary artery intimal sarcoma successfully treated using concurrent chemoradiotherapy and subsequent chemotherapy. Int Cancer Conf J. 2019; 8: 71-76

[9] Reed S, Lynch E, Silverman J. Invasive pulmonary artery intimal sarcoma: a rare case of an aggressive tumor with extended survival. Am J Clin Pathol. 2018; 149(Suppl 1): S111.

[10] Mussot S, Ghigna MR, Mercier O, et al. Retrospective institutional study of 31 patients treated for pulmonary artery sarcoma. Eur J Cardiothorac Surg. 2013; 43: 787-793.

[11] Anderson RH, Wilcox BR. Understanding cardiac anatomy: the prerequisite for optimal cardiac surgery. Ann Thorac Surg. 1995; 59: 1366-1375

[12] Bernard J, Yi ES. Pulmonary thromboendarterectomy: a clinicopathologic study of 200 consecutive pulmonary thromboendarterectomy cases in one institution. Hum Pathol. 2007; 38: 871877.

[13] Nagy P, Tomcsányi I, Magyar É. Intimal sarcoma of pulmonary artery. [Az arteria pulmonalis intima sarcomája.] LAM 2009; 19: 219-221. [Hungarian]

[14] Parish JM, Rosenow EC 3rd, Swensen SJ, et al. Pulmonary artery sarcoma. Clinical features. Chest 1996; 110: 1480-1488.

[15] Luthra S, Gallo A, Anthony S, et al. Primary pulmonary artery sarcoma presenting as right heart failure. Eur J Cardiothorac Surg. 2012; 42: 591 .
[16] Terra RM, Fernandez A, Bammann RH, et al. Pulmonary artery sarcoma mimicking a pulmonary artery aneurysm. Ann Thorac Surg. 2008; 86: 1354-1355.

[17] Attiná D, Niro F, Tchouanté P, et al. Pulmonary artery intimal sarcoma. Problems in the differential diagnosis. Radiol Med. 2013; 118: 1259-1268.

[18] Wijesuriya S, Chandratreya L, Medford AR. Chronic pulmonary emboli and radiologic mimics on CT pulmonary angiography: a diagnostic challenge. Chest 2013; 143: 1460-1471.

[19] Fletcher CD, Bridge JA, Hogendoorn P, et al. (eds.) WHO Classification of Tumours of Soft Tissue and Bone. Fourth Edition. World Health Organization, Geneva, 2013. ISBN-13 9789283224341.

[20] Huo L, Moran CA, Fuller GN, et al. Pulmonary artery sarcoma: a clinicopathologic and immunohistochemical study of 12 cases. Am J Clin Pathol. 2006; 125: 419-424.

[21] Bode-Lesniewska B, Zhao J, Speel EJ, et al. Gains of 12q13-14 and overexpression of MDM2 are frequent findings in intimal sarcomas of the pulmonary artery. Virchows Arch. 2001; 438: $57-65$.

[22] Dewaele B, Floris G, Finalet-Ferreiro J, et al. Coactivated platelet-derived growth factor receptor $\alpha$ and epidermal growth factor receptor are potential therapeutic targets in intimal sarcoma. Cancer Res. 2010; 70: 7304-7314.

[23] Vega F, Medeiros LJ, Bueso-Ramos CE, et al. Hematolymphoid neoplasms associated with rearrangements of PDGFRA, PDGFRB, and FGFRl. Am J Clin Pathol. 2015; 144: 377-392.

[24] Keel SB, Bacha E, Mark EJ, et al. Primary pulmonary sarcoma: a clinicopathologic study of 26 cases. Mod Pathol. 1999; 12: 1124-1131.

[25] Bacha EA, Wright CD, Grillo HC, et al. Surgical treatment of primary pulmonary sarcomas. Eur J Cardiothorac Surg. 1999; 15: 456-460.

[26] Blackmon SH, Rice DC, Correa AM, et al. Management of primary pulmonary artery sarcomas. Ann Thorac Surg. 2009; 87: 977-984.

[27] Tavora F, Montgomery E, Epstein JI. A series of vascular tumors and tumorlike lesions of the bladder. Am J Surg Pathol. 2008; 32: 1213-1219.

[28] Hoiczyk M, Iliodromitis K, Bauer S, et al. Intimal sarcoma of the pulmonary artery with unusual findings: a case report. Clin Res Cardiol. 2012; 101: 397-401.

[29] Wong HH, Gounaris I, McCormack A, et al. Presentation and management of pulmonary artery sarcoma. Clin Sarcoma Res. $2015 ; 5: 3$

[30] Umezawa K, Takamura K, Yamamoto M, et al. Pulmonary artery intimal sarcoma. Am J Respir Crit Care Med. 2014; 190: e67e68.

[31] Chen X, Ren S, Li A, et al. A case report of chemo-sensitive intimal pulmonary artery sarcoma. Cell Biochem Biophys. 2014; 68: 153-157.

[32] Funatsu Y, Hirayama M, Shiraishi J, et al. Intimal sarcoma of the pulmonary artery treated with pazopanib. Intern Med. 2016; 55: 2197-2202.
(Zombori Tamás dr., Szeged, Állomás u. 1., 6725 e-mail: zomtam@gmail.com)

A cikk a Creative Commons Attribution 4.0 International License (https://creativecommons.org/licenses/by/4.0/) feltételei szerint publikált Open Access közlemény, melynek szellemében a cikk bármilyen médiumban szabadon felhasználható, megosztható és újraközölhető, feltéve, hogy az eredeti szerző és a közlés helye, illetve a CC License linkje és az esetlegesen végrehajtott módosítások feltüntetésre kerülnek. (SID_1) 